\title{
Pharmacovigilance in oncology: pattern of spontaneous notifications, incidence of adverse drug reactions and under-reporting
}

\author{
Marília Berlofa Visacri', Cinthia Madeira de Souza', Rafaela Pimentel ${ }^{2}$, Cristina Rosa Barbosa ${ }^{3}$, \\ Catarina Miyako Shibata Sato ${ }^{4}$, Silvia Granja ${ }^{4}$, Mécia de Marialva ${ }^{4}$, Carmen Silvia Passos Lima ${ }^{5}$, \\ Priscila Gava Mazzola ${ }^{1}$, Patrícia Moriel ${ }^{1, *}$
}

${ }^{1}$ Department of Clinical Pathology, School of Medical Sciences, State University of Campinas, Campinas, SP, Brazil, ${ }^{2}$ Institute of Biology, State University of Campinas, Campinas, SP, Brazil, ${ }^{3}$ Chemotherapy Preparation Unit, Hospital of Clinics of State University of Campinas, Campinas, SP, Brazil, ${ }^{4}$ Pharmacy Service, Hospital of Clinics of State University of Campinas, Campinas, SP, Brazil, ${ }^{5}$ Department of Clinical Medicine, School of Medical Sciences, State University of Campinas, Campinas, SP, Brazil

The high toxicity and narrow therapeutic window of antineoplastic agents makes pharmacovigilance studies essential in oncology. The objectives of the current study were to analyze the pattern of spontaneous notifications of adverse drug reactions (ADRs) in oncology patients and to analyze the incidence of ADRs reported by outpatients on antineoplastic treatment in a tertiary care teaching hospital. To compose the pattern of ADR, the notification forms of reactions in oncology patients in 2010 were reviewed, and the reactions were classified based on the drug involved, mechanism, causality, and severity. To evaluate the incidence of reactions, a questionnaire at the time of chemotherapy was included, and the severity was classified based on the Common Terminology Criteria. The profiles of the 10 responses reported to the Pharmacovigilance Sector were type B, severe, possible, and they were primarily related to platinum compounds and taxanes. When the incidence of reactions was analyzed, it was observed that nausea, alopecia, fatigue, diarrhea, and taste disturbance were the most frequently reported reactions by oncology patients, and the grade 3 and 4 reactions were not reported. Based on this analysis, it is proposed that health professionals should be trained regarding notifications and clinical pharmacists should increasingly be brought on board to reduce under-reporting of ADRs.

Uniterms: Pharmacovigilance. Oncovigilance. Drugs/adverse reactions. Adverse drug reactions/underreporting. Adverse drug reactions/Spontaneous notification. Clinical pharmacy.

Estudos de farmacovigilância são imprescindíveis em oncologia, pois os antineoplásicos possuem alta toxicidade e estreita janela terapêutica. Os objetivos deste estudo foram analisar o perfil das notificações espontâneas de reações adversas a medicamentos (RAM) em pacientes oncológicos e a incidência de RAM ao tratamento antineoplásico em um hospital terciário e universitário. Para compor o perfil de RAM, revisaram-se os formulários de notificação de reações em pacientes oncológicos do ano de 2010 e classificaram-se as reações conforme o medicamento envolvido, mecanismo, causalidade e gravidade. Para avaliar a incidência de reações, aplicou-se um questionário no momento da quimioterapia e a gravidade foi classificada pelos Critérios Comuns de Toxicidade. Apenas 10 reações foram notificadas ao Setor de Farmacovigilância, cujo perfil encontrado foi tipo B, grave, possível, e foram principalmente relacionadas aos compostos de platina e taxanos. Na análise da incidência das reações, observou-se que náusea, alopecia, fadiga, diarreia e distúrbio do paladar foram as reações mais frequentes relatadas por pacientes oncológicos, e as reações grau 3 e 4 não foram notificadas. De acordo com essas análises, propõe-se que os profissionais da saúde sejam treinados quanto às notificações e que farmacêuticos clínicos sejam cada vez mais inseridos neste contexto para redução da subnotificação de RAM.

Unitermos: Farmacovigilância. Oncovigilância. Medicamentos/reações adversas. Antineoplásicos/ reações adversas. Reações adversas a medicamentos/subnotificação. Reações adversas a medicamentos/ notificação espontânea. Farmácia clínica.

\footnotetext{
*Correspondence: P. Moriel. Departamento de Patologia Clínica, Faculdade de Ciências Médicas, Universidade Estadual de Campinas. Rua Alexander Fleming, 105, 13083-881 - Campinas - SP, Brasil. E-mail: morielpa@fcm.unicamp.br
} 


\section{INTRODUCTION}

Pharmacovigilance is defined as a set of activities designed to identify and evaluate the effects of the acute and chronic use of pharmacological treatments in the population or subgroups exposed to specific treatments (Laporte, Carné, 1993). However, this concept has changed over the decades, which reflects the development of the associated activities. Thus, in 2002, the World Health Organization (WHO) expanded the definition of pharmacovigilance to science and activities related to the detection, assessment, understanding, and prevention of adverse effects or any drug related problem (WHO, 2002). The most frequently used pharmacovigilance model, the spontaneous notification of adverse drug reactions (ADRs), has proven inefficient because it usually results in under-reporting (Zancan et al., 2009). In several countries, pharmacists involved in pharmacovigilance have played an important role in the notification of suspected ADR by providing information and instructions on the safe and appropriate use of medicines, in addition to reducing the prevalence of ADRs and underreporting (Van-Grootheest, Jong-Van Den Berg, 2005). This is possible because the pharmacists who directly advise patients, especially within the context of pharmaceutical care, are more likely to detect ADRs.

Pharmacovigilance studies are essential in oncology. Antineoplastic agents are well studied and are extremely beneficial in cancer treatment, but they are used with caution due to their high toxicity and narrow therapeutic window (Gandhi et al., 2005). ADRs are so common and predictable in oncology that they came around to being accepted as an inevitable component of the treatment (Lau et al., 2004). Thus, onco-pharmacovigilance was developed, which is a subsystem of monitoring drugs derived from pharmacovigilance to monitor ADRs to cytotoxic antineoplastic drugs (Cobert, Biron, 2002; Albini et al., 2012).

Pharmacists specialized in oncology are responsible for a wide variety of functions, including monitoring, notification, prevention, and relief of reactions associated with chemotherapy (Liekweg et al., 2004). In a Japanese study, pharmacists were responsible for the prevention and treatment of emesis, peripheral neuropathy, handfoot syndrome, mucositis, localized pain, constipation, vascular pain, allergy, hyperglycemia, diarrhea and other conditions (Iihara et al., 2011). Lau et al., (2004) studied the preventability of reactions in oncology patients and found that $53 \%$ of the reactions such as alopecia cannot be prevented, whereas $45 \%$ and $2 \%$ of the reactions are probably and definitely preventable, respectively.

Studies that shows the incidence of ADRs to chemotherapy are scarce, which hinders the actual understanding of their severity and frequency of occurrence in clinical practice. Therefore, studies that report these adverse results can assist the multidisciplinary team in patient education and further suggest preventive procedures and medications. Thus, the adherence to treatment, clinical condition, and response to chemotherapy can be improved, reinforcing the existing review studies that suggest alternatives for the prevention and treatment of ADRs induced by chemotherapy (Iki, Urabe, 2000; Boige, Ducreax, 2001; Yoshida, 2002; Sharma et al., 2005; Yamamoto, Iwase, 2012).

Hence, the primary objectives of the current study was to analyze the pattern of spontaneous notification of suspected ADRs affecting oncology patients at a tertiary care teaching hospital, integrated with the Pharmacovigilance Program from the Brazilian National Health Surveillance Agency (ANVISA) during 2010, and to assess the incidence of ADRs related to antineoplastic treatment and the degree of toxicity reported by patients at the Chemotherapy Clinic.

\section{MATERIAL AND METHODS}

This is a descriptive and exploratory study in the field of pharmacovigilance, in which the spontaneous notifications of suspected ADRs affecting oncology patients were analyzed, the incidence of ADRs related to antineoplastic treatment, and the degrees of toxicity (Figure 1a and 1b), in a large (403 beds and outpatient units), tertiary care teaching hospital in the state of São Paulo (Hospital of Clinics, University of Campinas), integrated with the Pharmacovigilance Program of the Brazilian National Surveillance Agency Sanitary (ANVISA). The Research Ethics Committee of the institution approved the study.

\section{Spontaneous Notifications of Suspected ADRs that Affected Cancer Patients}

Different health professionals can notify suspected ADR by submitting a form to the Pharmacovigilance Sector of the hospital. The pharmacist reviews notifications to supplement the data by studying medical records, interviewing the professionals involved in the case, and monitoring patients from the point of notification to the resolution of the case or till their discharge from the hospital, to gather updated information. Subsequently, the pharmacist reports the reactions to ANVISA online.

It were analyzed all the notification forms on suspected ADR that have affected oncology patients 


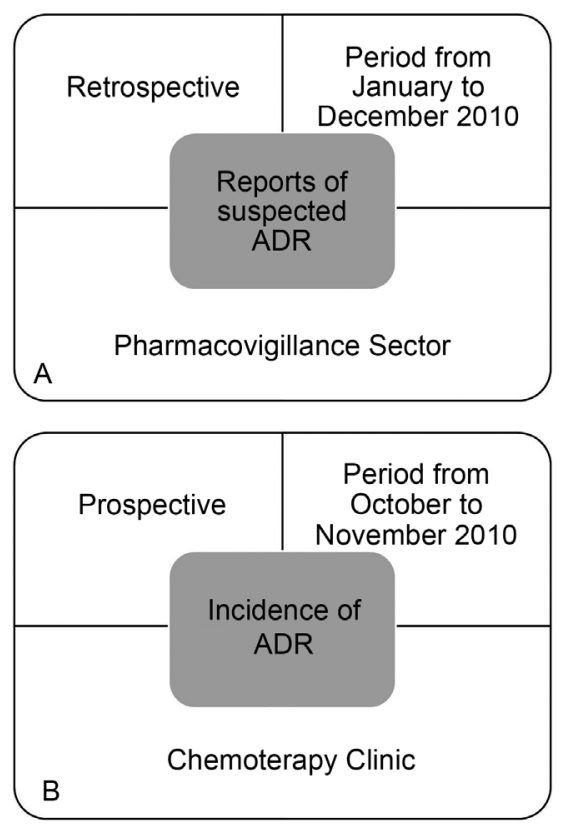

FIGURE 1 - Schematic of the study design. (A) Spontaneous notifications of suspected adverse drug reactions (ADRs) affecting oncology patients and (B) Incidence of adverse drug reactions (ADRs) and degrees of toxicity in the Chemotherapy Clinic.

(both inpatients as outpatients) from January to December 2010. Of the hospitalized patients, the reactions that occurred during the hospitalization period and that led to the hospital admission were studied. Reports of the suspected reaction in patients of both genders and of any age were included. The notification of suspected ADR was analyzed, including patient data, such as gender, age, type of neoplasm, comorbidities, possible risk factors, allergies, the description of the reaction and its start date and end, the drugs involved and the suspected drug (generic name, route of administration, dose, and posology), and the antineoplastic protocol.

For classification of drugs in drug groups, the third and fourth levels of the Anatomical Therapeutic Chemical Classification (ATC) (WHO, 2013) were used. Each reaction was characterized as follows. The reaction mechanism, using the classification proposed by Rawlins and Thompson (1998) (type A and B); causality, using the Naranjo Algorithm (Naranjo et al., 1981) (doubtful, possible, probable, and definite); and severity, according to Coêlho et al., (1999) (mild, moderate, severe, and fatal).

\section{Incidence of ADRs and Degrees of Toxicity in the Chemotherapy Clinic}

The Chemotherapy Clinic of the hospital in question is responsible for the intravenous antineoplastic treatment of patients with solid tumors, whereas gynecological tumors (breast, ovary, and uterus) are usually not treated in this clinic.

From October to November 2010, it were included all patients who underwent chemotherapy at the clinic on the day of the interview (regardless of personal characteristics, treatment protocol, and type of neoplasm), provided they agreed to answer the questionnaire and were not undergoing chemotherapy for the first time. Based on the protocols, both types of intravenous antineoplastic drugs (cytotoxins and monoclonal antibodies) were considered.

At the time of drug infusion, the patients were either questioned about the onset of a reaction during the session on the day of the interview or related to previous sessions of the same chemotherapy protocol. They were also questioned about ADRs that arise after the chemotherapy session (h or days) that occurred at least once during treatment with the same protocol. The questionnaire also included specific questions to assess the severity of ADRs, which allowed classifying them according to their degree of toxicity.

The following data for characterization of patients were collected: identification, gender, age, weight, height, type of neoplasm, and antineoplastic protocol. The reactions investigated were alopecia, dyspepsia, obstipation, diarrhea, taste disturbance, pain, fatigue, fever, insomnia, mucositis, nausea, hiccups, drowsiness, dizziness, tremor, and vomiting; of these, dyspepsia, diarrhea, fatigue, nausea, obstipation, dizziness, and vomiting were classified according to the degree of toxicity (grade 1 to 4 ) using the National Cancer Institute Common Terminology Criteria for Adverse Events (CTCAE) (version 3) (2011).

\section{RESULTS}

\section{Spontaneous Notifications of Suspected ADRs that Affected Cancer Patients}

On analyzing the spontaneous notifications of suspected ADR occurring in oncology outpatients and inpatients, 10 notifications were found, 7 of which were antineoplastic, and they constituted $37.0 \%$ of the total ADRs recorded in 2010 (Table I). The mean age was 46.6 \pm 20.6 years (minimum age: 19 years, maximum age: 70 years) and the majority patients were male $(70.0 \%)$ (Table II). The therapeutic classes of drugs suspected of causing the reactions included: 3 plant alkaloids and other natural products (podophyllotoxin derivatives and taxanes) (30.0\%); 3 other antineoplastic agents 
(platinum compounds) (30.0\%); 1 reaction related to an antithrombotic agent (vitamin $\mathrm{K}$ antagonist) $(10.0 \%) ; 1$ reaction to an antibacterial (glycopeptide antibacterial) $(10.0 \%) ; 1$ reaction to an antimycotic agent for systemic use (antibiotics) (10.0\%), and 1 to a cytotoxic antibiotic and related substances (other cytotoxic antibiotics) (10.0\%).

The mechanism of $8(80.0 \%)$ of the reactions was of the type B. In terms of severity, there was no fatal reaction; 4 reactions $(40.0 \%)$ were classified as severe because they directly threatened the life of the patient; 3 reactions $(30.0 \%)$ changed their normal activities and/or caused hospitalization and were classified as moderate, and 3 $(30.0 \%)$ were classified as mild, as they corresponded to unimportant reactions, since they did not substantially affect the patient's life. Regarding causality, only 1 reaction $(10.0 \%)$ was classified as defined, $3(30.0 \%)$ were probable, $6(60.0 \%)$ possible, and no reaction was classified as doubtful.
Therefore, the pattern observed was a type B reaction, severe and primarily affecting males; the pharmacological groups that caused the reactions were the plant alkaloids and other natural products (podophyllotoxin derivatives and primarily taxanes) and other antineoplastic agents (platinum compounds).

\section{Incidence of ADRs and Degrees of Toxicity in the Chemotherapy Clinic}

One hundred and two patients were interviewed, of whom 61 were men $(59.8 \%)$. The average age corresponded to $55.9 \pm 14.9$ years (minimum age: 17 years, maximum age: 82 years). Gastrointestinal cancer and treatment with FLOX (oxaliplatin + fluorouracil + leucovorin) were the most frequent cases encountered (Table III). The data showed that patients with sarcomas, nerve tissue cancer, and head and neck cancer were those

TABLE I - Description of spontaneous notifications of adverse drug reactions (ADRs) presented by oncology outpatients and inpatients from January to December 2010, Pharmacovigilance Sector (drug group; drug name; and disease and drug use)

\begin{tabular}{|c|c|c|c|}
\hline Notification & Drug Group & Drug(s) involved & Disease and drug use \\
\hline 1 & $\begin{array}{c}\text { B01AA } \\
\begin{array}{c}\text { Antithrombotic agent (vitamin K } \\
\text { antagonists) }\end{array}\end{array}$ & $\begin{array}{l}\text { Warfarin } \\
\text { (B01AA03) }\end{array}$ & $\begin{array}{l}\text { Multiple Myeloma. Prophylaxis of } \\
\text { thrombotic event }\end{array}$ \\
\hline 2 & $\begin{array}{c}\text { J01XA } \\
\begin{array}{c}\text { Other antibacterials (glycopeptides } \\
\text { antibacterials) }\end{array} \\
\end{array}$ & $\begin{array}{l}\text { Vancomycin } \\
\text { (J01XA01) }\end{array}$ & $\begin{array}{c}\text { Acute Myeloid Leukemia. Febrile } \\
\text { Neutropenia }\end{array}$ \\
\hline 3 & $\begin{array}{c}\text { J02AA } \\
\begin{array}{c}\text { Antimycotics for systemic use } \\
\text { (antibiotics) }\end{array} \\
\end{array}$ & $\begin{array}{l}\text { Amphotericin B } \\
\text { (J02AA01) }\end{array}$ & $\begin{array}{l}\text { Acute Myeloid Leukemia. } \\
\text { Filamentous fungus infection }\end{array}$ \\
\hline 4 & $\begin{array}{c}\text { L01CB } \\
\text { Plant alkaloids and other natural } \\
\text { products (podophyllotoxin } \\
\text { derivatives) }\end{array}$ & $\begin{array}{l}\text { Etoposide (PEB regimen: cisplatin, } \\
\text { etoposide, and bleomycin) } \\
\text { (L01CB01) }\end{array}$ & Malignant neoplasm of testis \\
\hline 5 & \multirow{2}{*}{$\begin{array}{l}\text { L01CD } \\
\text { Plant alkaloids and other } \\
\text { natural products (taxanes) }\end{array}$} & $\begin{array}{l}\text { Paclitaxel (monochemotherapy) } \\
\text { (L01CD01) }\end{array}$ & Kaposi's sarcoma \\
\hline 6 & & $\begin{array}{l}\text { Docetaxel (monochemotherapy) } \\
\text { (L01CD02) }\end{array}$ & Malignant neoplasm of prostate \\
\hline 7 & $\begin{array}{c}\text { L01DC } \\
\text { Cytotoxic antibiotics and related } \\
\text { substances (other cytotoxic } \\
\text { antibiotics) } \\
\end{array}$ & $\begin{array}{c}\text { Bleomycin (ABVD regimen: } \\
\text { doxorubicin, bleomycin, vinblastine, } \\
\text { and dacarbazine) } \\
\text { (L01DC01) }\end{array}$ & Hodgkin’s Lymphoma \\
\hline 8 & \multirow{3}{*}{$\begin{array}{c}\text { L01XA } \\
\text { Other Antineoplastic agents } \\
\text { (platinum compounds) }\end{array}$} & $\begin{array}{l}\text { Cisplatin (monochemotherapy) } \\
\text { (L01XA01) }\end{array}$ & Malignant neoplasm of the oral cavity \\
\hline 9 & & $\begin{array}{c}\text { Cisplatin (regimen: cisplatin, } \\
\text { doxorubicin, methotrexate) } \\
\text { (L01XA01) }\end{array}$ & Malignant neoplasm of bone \\
\hline 10 & & $\begin{array}{l}\text { Carboplatin (regimen: carboplatin } \\
\text { and paclitaxel) (L01XA02) }\end{array}$ & Malignant neoplasm of ovary \\
\hline
\end{tabular}


TABLE II - Description of spontaneous notifications of adverse drug reactions (ADRs) presented by oncology outpatients and inpatients from January to December 2010, Pharmacovigilance Sector (patient age; gender; description of the reaction; and classification according to the mechanism, causality, and severity)

\begin{tabular}{|c|c|c|c|}
\hline Notification & $\begin{array}{l}\text { Patient age } \\
\text { and gender }\end{array}$ & Description of the reaction & $\begin{array}{l}\text { Classification according to the } \\
\text { mechanism, causality, and severity }\end{array}$ \\
\hline 1 & $\begin{array}{l}59 \text { years } \\
\text { Female }\end{array}$ & $\begin{array}{l}\text { Ecchymosis, petechiae without rectal or mucosa } \\
\text { bleeding, and coagulopathy }\end{array}$ & Type A, possible, and severe \\
\hline 2 & $\begin{array}{l}43 \text { years } \\
\text { Male }\end{array}$ & $\begin{array}{l}\text { Severe urticarial reaction (skin rash, itching, and } \\
\text { fever) }\end{array}$ & Type B, probable, and moderate \\
\hline 3 & $\begin{array}{l}61 \text { years } \\
\text { Female }\end{array}$ & $\begin{array}{l}\text { Tremors, tachycardia, and oxygen saturation during } \\
\text { infusion }\end{array}$ & Type B, probable, and moderate \\
\hline 4 & $\begin{array}{l}19 \text { years } \\
\text { Male }\end{array}$ & $\begin{array}{l}\text { Exaggerated hypersensitivity reaction at the } \\
\text { beginning of the infusion of etoposide ( } 1 \text { st cycle) }\end{array}$ & Type B, probable, and severe \\
\hline 5 & $\begin{array}{l}64 \text { years } \\
\text { Male }\end{array}$ & Swelling at the infusion site & Type B, definite, and mild \\
\hline 6 & $\begin{array}{l}70 \text { years } \\
\text { Male }\end{array}$ & $\begin{array}{l}\text { Blackish pigmentation on vein where the medication } \\
\text { was infused }\end{array}$ & Type B, probable, and mild \\
\hline 7 & $\begin{array}{l}24 \text { years } \\
\text { Male }\end{array}$ & Stevens-Johnson syndrome & Type B, probable, and severe \\
\hline 8 & $\begin{array}{l}35 \text { years } \\
\text { Male }\end{array}$ & Orange pigmentation in nails (onychopathy) & Type B, probable, and mild \\
\hline 9 & $\begin{array}{l}23 \text { years } \\
\text { Male }\end{array}$ & Acute kidney injury (AKI) & Type A, possible, and moderate \\
\hline 10 & $\begin{array}{l}68 \text { years } \\
\text { Female }\end{array}$ & $\begin{array}{l}\text { Anaphylaxis during administration of carboplatin } \\
\qquad(10 \text { th cycle) }\end{array}$ & Type B, probable, and severe \\
\hline
\end{tabular}

TABLE III - Neoplasms, antineoplastic protocols, and adverse drug reactions (ADRs) of outpatients interviewed in the Chemotherapy Clinic from October to November 2010

\begin{tabular}{lccc}
\hline Neoplasms and Antineoplastic protocols & Number of patients & Percentage (\%) & ADRs per patient (mean) \\
\hline Gastrointestinal Cancer & 67 & 65.7 & 3.4 \\
FLOX & 23 & 22.5 & 2.8 \\
5-FU/LV & 16 & 15.7 & 3.1 \\
IFL Saltz & 12 & 11.8 & 4.3 \\
IFL Saltz + Bevacizumab & 5 & 4.9 & 4.2 \\
CDDP + Gencitabin & 3 & 2.9 & 2.7 \\
CDDP + Docetaxel & 2 & 1.9 & 8.5 \\
Bevacizumab ${ }^{(a)}$ & 1 & 1.0 & 3.0 \\
Carboplatin + Paclitaxel & 1 & 1.0 & 2.0 \\
IFL Saltz + Cetuximab & 1 & 1.0 & 4.0 \\
Cetuximab + Irinotecan & 1 & 1.0 & 4.0 \\
CDDP + Etoposide & 1 & 1.0 & 3.0 \\
Gencitabin & 1 & 1.0 & 5.0 \\
Head and Neck Cancer & 8 & 7.8 & 5.1 \\
CDDP & 4 & 3.9 & 4.5 \\
Carboplatin + Paclitaxel & 2 & 1.9 & 6.5 \\
\hline
\end{tabular}


TABLE III - Neoplasms, antineoplastic protocols, and adverse drug reactions (ADRs) of outpatients interviewed in the Chemotherapy Clinic from October to November 2010 (cont.)

\begin{tabular}{|c|c|c|c|}
\hline Neoplasms and Antineoplastic protocols & Number of patients & Percentage (\%) & ADRs per patient (mean) \\
\hline Carboplatin & 1 & 1.0 & 2.0 \\
\hline Methotrexate & 1 & 1.0 & 8.0 \\
\hline Cancer of the Genitourinary Tract & 7 & 6.7 & 3.6 \\
\hline PEB & 3 & 2.7 & 2.0 \\
\hline CDDP + Etoposide & 1 & 1.0 & 4.0 \\
\hline VIP & 1 & 1.0 & 4.0 \\
\hline Docetaxel & 1 & 1.0 & 4.0 \\
\hline Docetaxel + Zoledronic acid & 1 & 1.0 & 7.0 \\
\hline Cancer of the Respiratory Tract & 6 & 5.9 & 4.8 \\
\hline Carboplatin + Paclitaxel & 4 & 3.9 & 3.7 \\
\hline Carboplatin + Gencitabin & 1 & 1.0 & 7.0 \\
\hline CDDP + Etoposide & 1 & 1.0 & 7.0 \\
\hline Sarcomas & 5 & 4.9 & 5.8 \\
\hline CDDP + Doxorubicin & 2 & 1.9 & 7.5 \\
\hline Ifosfamide & 1 & 1.0 & 7.0 \\
\hline Paclitaxel & 1 & 1.0 & 5.0 \\
\hline $\mathrm{CAV}+\mathrm{IFO} / \mathrm{VP}$ & 1 & 1.0 & 8.0 \\
\hline Skin Cancer & 3 & 3.0 & 3.0 \\
\hline CVD & 3 & 3.0 & 3.0 \\
\hline Nerve Tissue Cancer & 3 & 3.0 & 5.7 \\
\hline Doxorubicin + Ifosfamide & 1 & 1.0 & 6.0 \\
\hline $\mathrm{IFO} / \mathrm{VP}$ & 1 & 1.0 & 6.0 \\
\hline Ifosfamide & 1 & 1.0 & 5.0 \\
\hline Gynecological Cancer & 3 & 3.0 & 4.0 \\
\hline Carboplatin + Doxorubicin & 2 & 2.0 & 4.0 \\
\hline Trastuzumab & 1 & 1.0 & 4.0 \\
\hline
\end{tabular}

Legend: FLOX: oxaliplatin + fluorouracil + leucovorin; 5-FU/LV: fluorouracil + leucovorin; IFL Saltz: irinotecan + fluorouracil + leucovorin; CDDP: cisplatin; PEB: cisplatin + etoposide + bleomycin; VIP: etoposide + ifosfamide + cisplatin; IFO/VP: ifosfamide + etoposide; CVD: cisplatin + vimblastine + dacarbazine; CAV: cyclophosphamide + doxorubicin + vincristine. (a) In this protocol, the patient also uses capecitabine (oral antineoplastic).

with more ADRs (5.8, 5.7, and 5.1 ADRs per patient, respectively), as well as patients treated with $\mathrm{CAV}+$ IFO/VP (cyclophosphamide/doxorubicin/vincristine + ifosfamide/etoposide) and methotrexate (either with 8.0 ADRs per patients).

Some protocols include treatment with concomitant radiotherapy. Leucovorin and zoledronic acid mentioned above, although not antineoplastic agents, are present in some protocols. Leucovorin is used together with fluoropyrimidines, such as fluorouracil, to potentiate the therapeutic effects of these drugs. The zoledronic acid is used in the treatment of tumor-induced hypercalcemia and in patients with advanced malignant tumor with bone involvement or metastases. Other medications are also administered in intravenous drips during the chemotherapy session to reduce possible reactions, such as metoclopramide, ondansetron, dexamethasone, electrolyte replacers, ranitidine, diphenhydramine, mesna, and mannitol.

Table IV shows the incidence of ADRs reported by patients, which occur during and after the chemotherapy session. Nausea (59.8\%), alopecia (46.1\%), fatigue (46.1\%), diarrhea $(39.2 \%)$, and taste disturbance (31.4\%) were the five most reported reactions in the Chemotherapy Clinic. 
TABLE IV - Incidence of adverse drug reactions (ADRs) reported by outpatients on antineoplastic treatment at the Chemotherapy Clinic from October to November 2010

\begin{tabular}{lcc}
\hline ADRs & Number of patients & Percentage (\%) \\
\hline Nausea & 61 & 59.8 \\
Alopecia & 47 & 46.1 \\
Fatigue & 47 & 46.1 \\
Diarrhea & 40 & 39.2 \\
Taste Disturbance & 32 & 31.4 \\
Vomiting & 31 & 30.4 \\
Insomnia & 29 & 28.4 \\
Dizziness & 28 & 27.4 \\
Obstipation & 25 & 24.5 \\
Pain & 23 & 22.5 \\
Mucositis & 23 & 22.5 \\
Dyspepsia & 21 & 20.6 \\
Drowsiness & 20 & 19.6 \\
Fever & 17 & 16.7 \\
Tremor & 12 & 11.8 \\
Hiccups & 10 & 9.8 \\
\hline
\end{tabular}

Based on this analysis, oncology patients on antineoplastic treatment feel $3.8 \pm 2.4$ symptoms on average, with a range of $0-10$ reactions. Among the 102 patients analyzed, $9(8.8 \%)$ reported no reaction, 13 $(12.7 \%)$ had only one reaction, $8(7.8 \%)$ had 2 reactions, $14(13.7 \%)$ had 3 reactions, $19(18.6 \%)$ had 4 reactions, 38 $(37.3 \%)$ had 5 to 9 reactions, and only one patient $(1.0 \%)$ showed 10 reactions (treated with cisplatin + docetaxel).

When the ADRs investigated were classified (nausea, vomiting, diarrhea, constipation, dyspepsia, dizziness, and fatigue) into different degrees of toxicity (Table V), it was observed that $57.7 \%$ of the symptoms were of toxicity grade $1,26.5 \%$ were grade $2,11.1 \%$ were grade 3 , and $4.7 \%$ were grade 4 , but some of the symptoms investigated do not have grade rating 4 .

\section{DISCUSSION}

Under-reporting is recognized as a major limitation of the spontaneous ADR reporting system (GonzalezGonzalez et al., 2013), and may be the result of fear on the part of health professionals to formalize the occurrence, fear of punishment, difficulty in completing the form, or lack of understanding of what constitutes an ADR. In the review by Lopez-Gonzalez et al., (2009), factors including ignorance (only severe ADRs need to be reported), diffidence (fear of appearing ridiculous for reporting merely suspected ADRs), lethargy (lack of interest or time to find a report card, and other excuses), and insecurity (it is nearly impossible to determine whether or not a drug is responsible for a particular ADR were some causes of under-reporting. The current study demonstrated that notifications of ADRs per year in oncology patients are a very small number, especially considering the toxicity of chemotherapy, thus characterizing the under-reporting. Another study showed that 89 reactions caused by antineoplastic drugs were reported within one year. It was also realized in a tertiary care teaching hospital in a developing country and with outpatients and inpatients; however, the hospital had 1,400 beds, there were 258,119 patients who were admitted and those who visited the hospital as outpatients during the study period. The pharmacovigilance service included clinical pharmacists, and the information regarding the ADRs reported in the unit was periodically disseminated to health care

TABLE V - Distribution of patients according to the degree of toxicity of the adverse drug reactions (ADRs) presented by outpatients of the Chemotherapy Clinic from October to November 2010 (National Cancer Institute Common Terminology Criteria for Adverse Events, CTCAE, version 3)

\begin{tabular}{lccccc}
\hline \multirow{2}{*}{ ADRs } & $\begin{array}{c}\text { Number of } \\
\text { patients }\end{array}$ & Grade 1 & Grade 2 & Grade 3 & Grade 4 \\
\cline { 3 - 6 } & 61 & 60.7 & 29.5 & 9.8 & 0.0 \\
\hline Nausea & 47 & 46.8 & 31.9 & 2.1 & 19.2 \\
Fatigue & 40 & 52.5 & 25.0 & 17.5 & 5.0 \\
Diarrhea & 31 & 38.7 & 29.0 & 29.0 & 3.3 \\
Vomiting & 28 & 78.6 & 17.9 & 3.6 & 0.0 \\
Dizziness & 25 & 68.0 & 20.0 & 12.0 & 0.0 \\
Obstipation & 21 & 71.4 & 23.8 & 4.8 & 0.0 \\
Dyspepsia & & & & & \\
\hline
\end{tabular}


professionals of the hospital through a news bulletin that published twice in a year. Nevertheless, the authors reported the occurrence of under-reporting (Jose, Rao, 2006).

There are no studies analyzing the pattern of reactions reported by spontaneous notifications with an emphasis in oncology. However, studies by Mallik et al., (2007) and Prasad et al., (2013) analyzed the pattern of ADRs to chemotherapy in cancer inpatients admitted retrospectively and prospectively, respectively, which corroborated with the current results. Mallik et al., (2007) found a greater number of ADRs in men, between 61 and 70 years old (mean age $57.8 \pm 11.5$ years old), primarily administered cisplatin. Prasad et al., (2013) found similar results; most ADRs occurred in men, aged between 50 and 59 years old, on cisplatin therapy and were classified as probable through the Naranjo Algorithm.

There is a large standoff to identify the definite causality in oncology by the very structure of the Naranjo Algorithm. Several drugs are used concomitantly with the suspect medication; for example, 4 reactions to antineoplastic treatment occurred in patients on multidrug therapy. Also, patients have, in addition to cancer, other underlying diseases that end up confusing the diagnosis of ADR. Another standoff on proving the causal relationship is the determination of the plasma concentration of the drug, since therapeutic monitoring is not common. Even with the administration of therapeutic doses, plasma levels can be altered by deviations in product quality, genetic polymorphism, exaggerated sensitivity of the target tissue, drug interactions, and hepatic and renal dysfunctions. In contrast, no reaction was classified as doubtful, since many are described in the literature and package insert, such as vancomycin and urticarial reaction (Perrin-Lamarre et al., 2010), cisplatin and nephrotoxicity (Yao et al., 2007), carboplatin and anaphylaxis (Iwamoto et al., 2012), bleomycin and Stevens-Johnson syndrome (Giaccone et al., 1986), and etoposide and hypersensitivity reaction (Lindsay, Gaynon, 2012).

The two type A reactions have well-established mechanisms of reaction and are easier to classify as definite. However, in the case of warfarin, it was classified as possible because the patient, in addition to have undergone a nephrectomy, was concurrently treated with dexamethasone, whose interaction may result in increased risk of bleeding and abnormal coagulation (Klasco, 2013). Thus, the event presented may not have been an ADR but a consequence of drug interactions and/or decreased excretion of warfarin.

Because the type A reactions are predictable, reversible, treated with dose adjustments and can be avoided, the role of the clinical pharmacist gains importance. The notifications that include type A reaction demonstrate a clear need for a clinical pharmacist to monitor the patients. In the case of warfarin, inspecting the drug interactions before use would be necessary, and could lead to a reduction in the dose of warfarin to $50 \%$ for 4 days (Klasco, 2013), in addition to regular assessment of renal function and suitable dose adjustment. In the case of AKI induced by cisplatin, the pharmacist should be aware of the patient's renal function before administration of the antineoplastic, ensure that the patient is adequately hydrated and should guide the patients to increase fluid intake $24 \mathrm{~h}$ before and after chemotherapy, increase the amounts of antioxidants in food or vitamin supplementation, as well as propose protocols for the prevention and treatment of nephrotoxicity based on antioxidant drugs, and based on the mechanism of toxicity of cisplatin (Hsu, Guo, 2002; Miller et al., 2010).

With respect to the type B reactions, though they are unpredictable and of unknown mechanism of reaction, the pharmacist must be aware, for example, of previous exposure to platinum compounds, ensuring that corticosteroids and antihistaminics are administered prior to the infusion of the drug to prevent hypersensitivity reactions (CortijoCascajares et al., 2012). In addition, the pharmacist should warn the patients about the hyperpigmentation reaction, and advice against exposure to the sun.

The five most reported reactions identified in the Chemotherapy Clinic (nausea, alopecia, fatigue, diarrhea, and taste disturbance) are conform to those reported by Lau et al. (2004), who also investigated the most frequent reactions in oncology patients, except taste disturbance that was not measured by these researchers. The ten most common ADRs reported by Lau et al. (2004), included constipation, nausea with or without vomiting, fatigue, alopecia, drowsiness, myelosuppression, skin reactions, anorexia, mucositis, and diarrhea. The current study also showed that patients with sarcomas, nerve tissue cancer, and head and neck cancer showed more ADRs, as well as patients treated with CAV + IFO/VP and methotrexate.

Chemotherapy-induced nausea and vomiting (CINV) are the most feared and the most common symptoms that affect the quality of life, as the patient's routine is significantly affected by these symptoms, thus justifying the need for their effective management by health professionals. Iihara et al. (2011) demonstrated that pharmaceutical intervention to facilitate the use of antiemetics in the prophylaxis of CINV has a favorable result, i.e., increased number of patients with complete response at the acute and late phases of CINV. Cisplatin has a known high emetogenic potential ( $>90 \%$ of risk) 
(Hesketh et al., 1997). Therefore, it is important to avoid CINV, the antiemetic administration before (30 minutes before infusion of the antineoplastic agent) and after the chemotherapy session (3 days), from the first treatment cycle before the onset of the effect, and not just after nausea and vomiting, as frequently occurs in clinical practice. Highly emetogenic chemotherapy patients should be treated with the combination of the three agents for the prevention of acute and delayed CINV; an antagonist of the 5-HT3 receptor, dexamethasone and an antagonist of the NK1 receptor (aprepitant) (American Society of Clinical Oncology et al., 2006). Patients should also adopt non-pharmacological measures, such as avoid foods with a strong taste/odor, foods with excess fat, carbonated beverages, in addition to the stimulation of a hyperfractionated diet and oral hygiene (Rhodes, McDaniel, 2001).

Alopecia negatively affects the appearance, body image, sexuality, and self-esteem. Patients and family members often think that all individuals undergoing antineoplastic treatment will manifest this reaction. In this study, alopecia was the second most frequent effect; however, less than half of the patients presented it. This finding contradicts data found in the literature, where the estimated incidence for alopecia is $65 \%$ and is the third most frequent toxicity in cancer patients (Trueb, 2009). Adequate management practices can prevent and mitigate this adverse effect and increase the quality of life of oncology patients (Wang et al., 2006); however, the studied patients did not receive any intervention for alopecia. The low frequency observed in this study may be attributable to the fact that most patients were treated with 5-FU and oxaliplatin, which cause alopecia in low proportions (Trueb, 2009; Furue, 2005).

Fatigue affected almost half of the patients in this study and was the most severe symptom because some patients were confined to bed after a session of chemotherapy (grade 4 toxicity). The patients received no intervention for fatigue; however, they required appropriate management to reduce the frequency and severity of this reaction. There is still no consensus on the best treatment for fatigue. Based on a review (Payne et al., 2012), 116 studies administered pharmacological and non-pharmacological interventions related to the management of fatigue and weight loss in cancer patients, with the administration of eicosapentaenoic acid (EPA) being the primary pharmacological intervention and physical exercise and psychosocial support the main nonpharmacological intervention. Methylphenidate, modafinil, 1-carnitine, and corticosteroids are other drugs useful in the treatment of fatigue, although there is not much supporting evidence (Sarhill et al., 2001; Morrow et al., 2005; Gramignano et al., 2006; Hanna et al., 2006; Haq, Butt, 2007).

Diarrhea occurs because the epithelial cells of the gastrointestinal tract are destroyed by certain antineoplastic agents, such as fluorouracil and irinotecan, which results in poor digestion and absorption of nutrients (Shafi, Bresalier, 2010). In this study, diarrhea was the fourth most commonly reported ADR. When the patients developed this reaction, loperamide was administered. Loperamide has been recognized as a more effective pharmacological agent for treating diarrhea (Shafi, Bresalier, 2010; Benson et al., 2004), and its use should be adequately monitored.

Taste disturbance, such as hypogeusia (moderately altered taste), ageusia (loss of taste), and dysgeusia (change in taste), was the fifth most reported effect on outpatients of the Chemotherapy Clinic. This reaction is very common in individuals undergoing chemotherapy and culminates in loss of appetite and weight loss, including the anorexic condition. This weight loss caused by taste disturbance also leads to fatigue, as previously mentioned. Taste disturbance should be adequately treated so that patients are not affected by other morbidities that are caused by this reaction, as exposed. There are few effective pharmacological measures for taste disturbances, although reports suggest that vitamin D may have some beneficial effect in dysgeusia (Moser et al., 2011); however, pharmacological interventions are not administered at the study institution and management is mainly based on non-pharmacological measures that include dietary adjustments and oral hygiene.

As observed in the present study, there were grade 3 and 4 ADRs associated with chemotherapy, although most patients reported grade 1 symptoms. The Brazilian Society of Oncology Pharmacists (SOBRAFO) and the Brazilian National Agency for Sanitary Surveillance (ANVISA) recommend that all grade 3 and 4 reactions in oncology should be reported (Sobrafo, Anvisa, 2011). However, these reactions have not been notified in the Pharmacovigilance Sector of the hospital, which demonstrates that the healthcare professionals are not prepared to notify ADRs, even being a hospital integrated with the Pharmacovigilance Program of ANVISA. They do not possess a full understanding of the diagnosis of ADRs and the criteria to notify them, among other reasons already observed by Lopez-Gonzalez et al. (2009). A periodic training on spontaneous ADR reporting and pharmacovigilance must be provided for multidisciplinary team involved with the cancer care. The Pharmacovigilance Sector could also begin to implement the active surveillance for ADRs; the pharmacist could 
gather information on ADRs directly from a patient, a physician, or by reviewing medical records; trigger tools can be used for this process. News bulletins published by pharmacovigilance departments of hospitals and an individual feedback to reporters could also be an effective strategy for improving pharmacovigilance.

Thus, the pharmacist should actively participate in pharmacovigilance in oncology following the onset of ADRs to the treatment, recording grade 3 and 4 reactions in the pharmacovigilance systems, providing guidance for the rational use of medicines as well as pharmacological and non-pharmacological measures, developing guidelines for the prevention and treatment of ADR, and health education. The pharmacist must always be attentive so that ADRs are minimized during treatment.

\section{CONCLUSIONS}

This study has shown that pharmacovigilance is an increasingly important science in the hospital setting, especially in the oncology field. However, educating the health professionals about the need to notify these reactions is more important than studying ADRs. It was observed that oncology patients present several ADRs, including grade 3 and 4, which should be reported in the pharmacovigilance system. However, these pass by unreported, which contributes to the under-reporting in oncology. The training of health professionals working in hospitals on how, when and what to notify is essential to reduce under-reporting. In addition, it is proposed that a clinical pharmacist should be recruited in this process, as they are ideal professionals to efficiently perform the pharmacovigilance role. The present paper can also be used to educate patients, to demonstrate that there are many ADRs associated with chemotherapy, but most of these are not debilitating; thus adherence to antineoplastic treatment can be improved.

\section{ACKNOWLEDGEMENTS}

We are thankful to the Institutional Program of Scientific Initiation Scholarships (PIBIC) and the Foundation for Development of UNICAMP (FUNCAMP) for the financial support.

\section{REFERENCES}

ALBINI, A.; DONATELLI, F.; NOONAN, D.; D`ELIOS, M.M.; PRISCO, D. Bringing new players into the field: oncopharmacovigilance in the era of cardio-oncology. Intern. Emerg. Med., v.7, n.2, p.99-101, 2012.
AMERICAN SOCIETY OF CLINICAL ONCOLOGY; KRIS, M.G.; HESKETH, P.J.; SOMERFIELD, M.R.; FEYER, P.; CLARK-SNOW, R.; KOELLER, J.M.; MORROW, G.R.; CHINNERY, L.W.; CHESNEY, M.J.; GRALLA, R.J.; GRUNBERG, S.M. American society of clinical oncology guideline for antiemetics in oncology: update 2006. J. Clin. Oncol., v.24, n.18, p.2932-2947, 2006.

ANVISA. Agência Nacional de Vigilância Sanitária. Sociedade Brasileira de Farmacêuticos em Oncologia. Guia para notificações de reações adversas em oncologia. Belo Horizonte: SOBRAFO/ANVISA, 2011. Available at: http://www.sobrafo.org.br/site/public/docs/ATT00373.pdf. Accessed on: April 2013.

BENSON, A.B.; AJANI, J.A.; CATALANO, R.B., ENGELKING, C.; KORNBLAU, S.M.; WADLER, S. Recommended guidelines for the treatment of cancer treatment-induced diarrhea. J. Clin. Oncol., v.22, n.14, p.2918-2926, 2004.

BOIGE, V.; DUCREUX, M. Prevention and treatment of chemotherapy induced digestive toxicities. Bull. Cancer, v.88, n.2, p.163-173, 2001.

COBERT, B.L.; BIRON, P. Pharmacovigilance from A to Z: adverse drug event surveillence. Massachussets: Blackwell Science, 2002. 235 p.

COÊLHO, H.L.; ARRAIS, P.S.D.; GOMES, A.P. Sistema de farmacovigilância do Ceará: um ano de experiência. $\mathrm{Cad}$. Saúde Pública, v.15, n.3, p.631-640, 1999.

CORTIJO-CASCAJARES, S.; JIMÉNEZ-CEREZO, M.J.; HERREROS DE TEJADA, A. Review of hypersensitivity reactions to antineoplastic agents. Farm. Hosp., v.36, n.3, p.148-158, 2012.

FURUE, H. Oxaliplatin. Gan To Kagaku Ryoho, v.32, n.8, p.1195-1202, 2005.

GANDHI, T.K.; BARTEL, S.B.; SHULMAN, L.N; VERRIER, D.; BURDICK, E.; CLEARY, A.; ROTHSCHIDL, J.M.; LEAPE, L.L.; BATES, D.W. Medication safety in ambulatory chemotherapy setting. Cancer, v.104, n.11, p.2477-2483, 2005.

GIACCONE, G.; RISIO, M.; BONARDI, G.; CALCIATI, A. Stevens-Johnson syndrome and fatal pulmonary toxicity to combination chemotherapy containing bleomycin: a case report. Tumori, v.72, n.3, p.331-333, 1986. 
GONZALEZ-GONZALEZ, C.; LOPEZ-GONZALEZ, E.; HERDEIRO, M.T.; FIGUEIRAS, A. Strategies to improve adverse drug reaction reporting: a critical and systematic review. Drug Saf., v.36, n.5, p.317-328, 2013.

GRAMIGNANO, G.; LUSSO, M.R.; MADEDDU, C.; MASSA, E.; SERPE, R.; DEIANA, L.; LAMONICA, G.; DESSÌ, M.; SPIGA, C.; ASTARA, G.; MACCIÒ, A.; MANTOVANI, G. Efficacy of 1-carnitine administration on fatigue, nutritional status, oxidative stress, and related quality of life in 12 advanced cancer patients undergoing anticancer therapy. Nutrition, v.22, n.2, p.136-145, 2006.

HANNA, A.; SLEDGE, G.; MAYER, M.L.; HANNA, N.; EINHORN, L.; MONAHAN, P.; DAGGY, J.; BHATIA S. A phase II study of methylphenidate for the treatment of fatigue. Support. Care Cancer, v.14, n.3, p. 210-215, 2006.

HAQ, S.M.; BUTT, M. Cancer related fatigue during the cancer journey. Eur. J. Palliat. Care, v.14, n.13, p.96-98, 2007.

HESKETH, P.J.; KRIS, M.G.; GRUNBERG, S.M.; BECK, T.; HAINSWORTH, J.D.; HARKER, G. Proposal for classifying the acute emetogenicity of cancer chemotherapy. J. Clin. Oncol., v.15, n.1, p.103-109, 1997.

HSU, P.C.; GUO, Y.L. Antioxidant nutrients and lead toxicity. Toxicology, v.180, n.1, p.33-44, 2002.

IIHARA, H.; ISHIHARA, M.; MATSUURA, K.; KURAHASHI, S.; TAKAHASHI, T.; KAWAGUCHI, Y.; YOSHIDA, K.; ITOH, Y. Pharmacists contribute to the improved efficiency of medical practices in the outpatient cancer chemotherapy clinic. J. Eval. Clin. Pract., v.18, n.4, p.1-8, 2011.

IKI, S.; URABE, A. Prevention and treatment of side effects of cancer chemotherapy. Gan To Kagaku Ryoho, v.27, n.11, p.1635-1640, 2000.

IWAMOTO, T.; YUTA, A.; TABATA, T.; SUGIMOTO, H.; GABAZZA, E.C.; HIRAI, H.; KOJIMA, S.; OKUDA, M. Evaluation of basophil CD203c as a predictor of carboplatin-related hypersensitivity reaction in patients with gynecologic cancer. Biol. Pharm. Bull., v.35, n.9, p.1487-1495, 2012.

JOSE, J.; RAO, P.G.M. Pattern of adverse drug reactions notified by spontaneous reporting in an Indian tertiary care teaching hospital. Pharmacol. Res., v.54, n.3, p.226-233, 2006.
KLASCO, R.K. (Ed). DRUGDEX ${ }^{\circledR}$ System (2013). Thomson Micromedex, Greenwood Village, Colorado. Available at: http://www.micromedexsolutions.com/micromedex2/ librarian/. Accessed on: April 2013.

LAU, P.M.; STEWART, K.; DOOLEY, M. The ten most common adverse drug reactions (ADRs) in oncology patients: do they matter to you? Support. Care Cancer, v.12, n.9, p.626-633, 2004.

LAPORTE, J.R.; CARNÉ, X. Metodología epidemiológica básica em farmacovigilância. In: LAPORTE, J.R.; TOGNONI, G. Princípios de epidemiologia del medicamento. Barcelona: Masson-Salvat, 1993. p.111-130.

LIEKWEG, A.; WESTFELD, M.; JAEHDE, U. From oncology pharmacy to pharmaceutical care: new contributions to multidisciplinary cancer care. Support. Care Cancer, v.12, n.2, p.73-79, 2004.

LINDSAY, H.; GAYNON, P. Anaphylactic reaction to etoposide phosphate. Pediatr. Blood Cancer, v.59, n.4, p.765, 2012.

LOPEZ-GONZALEZ, E.; HERDEIRO, M.T.; FIGUEIRAS, A. Determinants of under-reporting of adverse drug reactions: a systematic review. Drug Saf., v.32, n.1, p.19-31, 2009.

MALLIK, S.; PALAIAN, S.; OJHA, P.; MISHRA, P. Pattern of adverse drug reactions due to cancer chemotherapy in a tertiary care teaching hospital in Nepal. Pak. J. Pharm. Sci., v.20, n.3, p.214-218, 2007.

MILLER, R.P.; TADAGAVADI, R.K.; RAMESH, G.; REEVES, W.B. Mechanisms of cisplatin nephrotoxicity. Toxins, v.2, n.11, p.2490-2518, 2010.

MORROW, G.R.; ANDREWS, P.L.; HICKOK, J.T.; ROSCOE, J.A.; MATTERSON, S. Fatigue associated with cancer and its treatment. Support. Care Cancer, v.10, n.5, p.289-298, 2002.

MOSEL, D.D.; BAUER, R.L.; LYNCH, D.P.; HWANG, S.T. Oral complications in the treatment of cancer patients. Oral Dis., v.17, n.6, p.550-559, 2011.

NARANJO, C.A.; BUSTO, U.; SELLERS, E.M.; SANDOR, P.; RUIZ, I.; ROBERTS, E.A.; JANECEK, E.; DOMECQ, C.; GREENBLATT, D.J. A method for estimating the probability of adverse drug reactions. Clin. Pharmacol. Ther, v.30, n.2, p.239-245, 1981. 
NATIONAL Cancer Institute. Common terminology criteria for adverse events. Available at: www.ctep.cancer.gov. Accessed on: November 2011.

PAYNE, C.; WIFFEN, P.J.; MARTIN, S. Interventions for fatigue weight loss in adults with advanced progressive illness. Cochrane Database Syst. Rev., 2012.

PERRIN-LAMARRE, A.; PETITPAIN, N.; TRECHOT, P.; CUNY, J.F.; SCHMUTZ, J.L.; BARBAUD, A. Glycopeptide-induced cutaneous adverse reaction: results of an immunoallergic investigation in eight patients. Ann. Dermatol. Vénéréol., v.137, n.2, p.101-105, 2010.

PRASAD, A.; DATTA, P.P.; BHATTACHARYA, J.; PATTANAYAK, C.; CHAUHAN, A.S.; PANDA, P. Pattern of adverse drug reactions due to cancer chemotherapy in a tertiary care teaching hospital in eastern India. $J$. Pharmacovigilance, v.1, n.2, p.107-111, 2013.

RAWLING, M.D.; THOMPSON, S.H.L. Mechanisms of adverse drug reactions. In: DAVIES, D.M.; FERNER, R.E.; DE GLANVILLE, H. (Ed.). Davies's textbook of adverse drug reactions. Londres: Chapman \& Hall Medical, 1998. p.40-64.

RHODES, V.A.; MCDANIEL, R.W. Nausea, vomiting, and retching: complex problems in palliative care. $C A$ Cancer J. Clin., v.51, n.4, p.232-248, 2001.

SARHILL, N.; WALSH, D.; NELSON, K.A.; HOMSI, J.; LEGRAND, S.; DAVIS, M.P. Methylphenidate for fatigue in advanced cancer: a prospective open-label pilot study. Am. J. Hosp. Palliat. Care, v.18, n.3, p.187-192, 2001.

SHAFI, M.A.; BRESALIER, R.S. The gastrointestinal complications of oncologic therapy. Gastroenterol. Clin. North Am., v.39, n.3, p.629-647, 2010.

SHARMA, R.; TOBIN, P.; CLARKE, S.J. Management of chemotherapy induced nausea, vomiting, oral mucosities and diarrhea. Lancet Oncol., v.6, n.2, p.93-102, 2005.
TRUEB, R.M. Chemotherapy-induced alopecia. Semin. Cutan. Med. Surg., v.28, n.1, p.11-14, 2009.

VAN GROOTHEEST, A.C.; JONG-VAN DEN BERG, L.T.W. The role and community pharmacists in pharmacovigilance. Res. Social Adm. Pharm., v.1, n.1, p.126-133, 2005.

WANG, J.; LU, Z.; AU, J.L. Protection against chemotherapyinduced alopecia. Pharm. Res., v.23, n.11, p.2505-2514, 2006.

WORLD Health Organization. Anatomical therapeutical chemical classification. Available at: http://www.whocc. no/atc_ddd_index/. Accessed on: April 2013.

WORLD Health Organization. Safety of medicines - a guide to detecting and reporting adverse drug reactions - why health professionals need to take actions. Geneva: WHO, 2002. Available at: http://archives.who.int/tbs/safety/esd_safety. pdf. Accessed on: April 2013.

YAMAMOTO, Y.; IWASE, H. Management for treatment induced adverse reaction chemotherapy. Nihon Rinsho Jpn. J. Clin. Med., v.70, n.7, p.672-676, 2012.

YAO, X.; PANICHPISAL, K.; KURTZMAN, N.; NUGENT, K. Cisplatin nephrotoxicity: a review. Am. J. Med.Sci., v.334, n.2, p.115-124, 2007.

YOSHIDA, K. Management and types of side effects in chemotherapy for lung cancer. Nihon Rinsho Jpn. J. Clin. Med., v.60, n.5, p.384-387, 2002.

ZANCAN, A.; LOCATELLI, C.; RAMELLA, F.; TATONI, P.; BACIS, G.; VECCHIOS, S.; MANZO, L. A new model of pharmacovigilance? A pilot study. Biomed. Pharmacother., v.63, n.6, p.451-455, 2009.

Received for publication on $11^{\text {th }}$ October 2013 Accepted for publication on $06^{\text {th }}$ February 2014 